\title{
Cloning and Functional Expression of an Aplysia 5-HT Receptor Negatively Coupled to Adenylate Cyclase
}

\author{
Annie Angers, ${ }^{1}$ Maksim V. Storozhuk, ${ }^{2}$ Thomas Duchaîne, ${ }^{1}$ Vincent F. Castellucci, ${ }^{2,3}$ and Luc DesGroseillers ${ }^{1,3}$ \\ ${ }^{1}$ Département de biochimie, ${ }^{2}$ Département de physiologie, and ${ }^{3}$ Centre de recherches en sciences neurologiques, \\ Université de Montréal, Montréal, Québec, Canada H3C 3J7
}

\begin{abstract}
Serotonin $(5-\mathrm{HT})$ is involved in the control of various behaviors in Aplysia californica, including reproduction, feeding, locomotion, circadian rhythm, synaptic plasticity, and synaptic growth. The large variety of functions of $5-\mathrm{HT}$ is mediated by different receptor subtypes that are coupled to different secondmessenger systems. Here, we report the cloning of a cDNA coding for an Aplysia G-protein-coupled 5-HT receptor (5$\left.H T_{a p 1}\right)$. Its deduced amino acid sequence resembles those of the $5-\mathrm{HT}_{1}$ receptor subfamily. When expressed in stable cell lines, $5-\mathrm{HT}_{\mathrm{ap} 1}$ exhibits high-affinity binding for the serotonergic radioligand $\left[\mathrm{N}-\right.$ methyl- $\left.{ }^{3} \mathrm{H}\right]$ lysergic acid diethylamide. This binding is competed by several 5-HT agonists and antagonists, and the pharmacological profile of inhibition has some similarities with those of $5-\mathrm{HT}_{1}$ and $5-\mathrm{HT}_{7}$ receptors. Application of $5-\mathrm{HT}$ or its agonists 5-carboxamidotryptamine maleate and ( \pm )-8-
\end{abstract}

Serotonin (5-HT) has a large variety of functions both in vertebrates and invertebrates. It plays a role in feeding, circadian rhythm, locomotion, reproduction, and modulation of defensive behavior (Hen, 1993; Weiger, 1997). In mollusks, pharmacological and electrophysiological studies showed that 5-HT is a neuromodulatory neurotransmitter that acts on at least six different receptor subtypes to activate different postsynaptic responses (Gerschenfeld and Paupardin-Trich, 1974; Kadan and Hartig, 1988). In mammals, molecular cloning has shown the existence of at least 14 5-HT receptor subtypes (Hoyer et al., 1994). These receptors, which are members of the G-protein-coupled receptor family, can be classified on the basis of sequence identity and on the nature of the second messenger systems with which they are coupled. The $5-\mathrm{HT}_{1,5}$ and $5-\mathrm{HT}_{4,6,7}$ subtypes inhibit or activate adenylate cyclase, respectively, whereas the $5-\mathrm{HT}_{2}$ subtype stimulates phospholipase C. By contrast, the $5-\mathrm{HT}_{3}$ subtype is a ligand-gated ion channel (Peroutka, 1995).

In the sensory neurons involved in defensive behavior, 5-HT increases the level of cAMP and activates protein kinase A (Bacskai et al., 1993), protein kinase C (Sugita et al., 1992; Byrne

\footnotetext{
Received Jan. 21, 1998; revised May 13, 1998; accepted May 15, 1998.

This work was supported by Medical Research Council of Canada grants to L.D.G. and V.F.C. A.A. and T.D. received studentships from the Fonds pour la Formation de Chercheurs et l'Aide à la Recherche du Québec and the Natural Sciences and Engineering Research Council of Canada, respectively. We thank Roger Bossé, Michel Bouvier, Michael Dennis, Jean Labrecque, André Laperrière, Sandrine Nouet, and Graciella Piñeyro for generous help and discussion in the pharmacological experiments, Christelle Bouchard for help in the library screening, and Louise Wickham for critical reading of this manuscript.

Correspondence should be addressed to Luc DesGroseillers, Département de biochimie, Université de Montréal, C.P. 6128, Succursale "Centre-Ville," Montréal, Québec, Canada H3C 3J7.

Copyright (C) 1998 Society for Neuroscience $\quad 0270-6474 / 98 / 185586-08 \$ 05.00 / 0$
}

hydroxy-2-(di- $n$-propyl-amino) tetralin hydrobromide on cells transformed with $5-\mathrm{HT}_{\mathrm{ap} 1}$ produced a dose-dependent inhibition of forskolin-stimulated cAMP accumulation. $5-\mathrm{HT}_{\mathrm{ap} 1}$ is thus negatively coupled to adenylate cyclase. The production of antiserum against the 5- $\mathrm{HT}_{\mathrm{ap} 1}$ receptor allowed us to examine its expression in animal tissues. The receptor protein is detected in every tissue examined, although it seems only weakly expressed in some samples. The receptor is also found in every ganglia of the nervous system, both in the sheath and in the neurons. $5-\mathrm{HT}_{\mathrm{ap} 1}$ mRNA is absent from the sheath, indicating that the protein observed there is probably located on the nerve terminals.

Key words: Aplysia; 5-HT; 5-HT, receptor; G-protein-coupled receptor; adenylate cyclase; inhibition and Kandel, 1996), and MAP kinase (Martin et al., 1997). These actions of 5-HT are expected to be mediated by different 5-HT receptors (Braha et al., 1990; Mercer et al., 1991; Ghirardi et al., 1992; Emptage and Carew, 1993). In the neuroendocrine bag cell clusters, which are involved in the regulation of the egg-laying behavior, the application of 5-HT inhibits the bag cell afterdischarge that is itself dependent on the stimulation of adenylate cyclase (Jennings et al., 1981). 5-HT has also been reported to inhibit inhibitory interneurons of the tail withdrawal reflex pathway (Xu et al., 1995). Altogether, these results strongly suggest that the major mammalian 5-HT receptor types all have functional homologs in Aplysia. Recently, genes encoding two homologous 5-HT receptors have been cloned in Aplysia. Both receptors stimulate phospholipase $\mathrm{C}$ in response to 5 - $\mathrm{HT}$ in a dose-dependent manner. However, they could not be readily grouped within any of the mammalian subgroups based on amino acid homologies (Li et al., 1995).

We have cloned and characterized cDNAs coding for an Aplysia 5-HT receptor with significant sequence and functional homologies to the members of the vertebrate $5-\mathrm{HT}_{1}$ receptor subfamily. Expression of 5- $\mathrm{HT}_{\mathrm{ap} 1}$ in mammalian cells shows that the receptor is able to specifically bind 5-HT at nanomolar concentrations, as well as diverse serotonergic ligands. In addition, 5-HT and 5-HT agonists induce inhibition of adenylate cyclase in cells stably expressing $5-\mathrm{HT}_{\mathrm{ap} 1}$. Using RT-PCR and Western blot analysis, we detected expression of this receptor in the CNS and in peripheral tissues.

\section{MATERIALS AND METHODS}

Compounds. $\left[2,8-{ }^{3} \mathrm{H}\right]$ Adenine and $\left[\mathrm{N}\right.$-methyl- $\left.{ }^{3} \mathrm{H}\right]$ lysergic acid diethylamide $\left(\left[{ }^{3} \mathrm{H}\right] \mathrm{LSD}\right)$ were purchased from DuPont NEN (Mississauga, Ontario, Canada). Forskolin, ATP, cAMP, 5-HT, and isobutylmethylxan- 


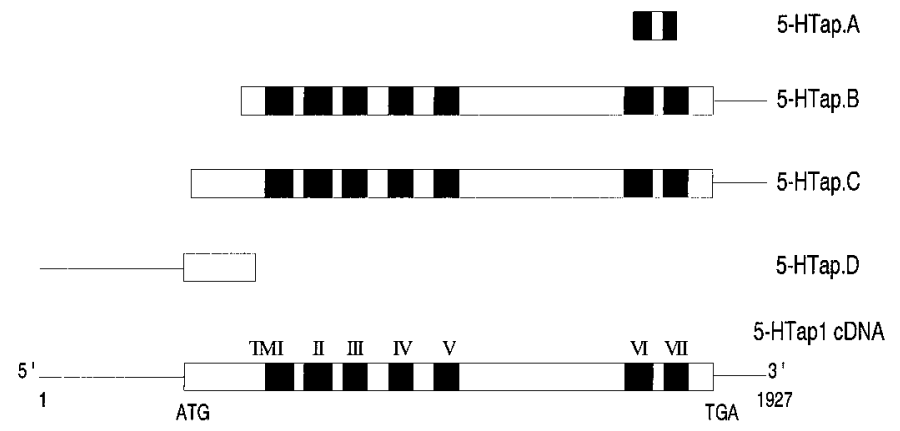

Figure 1. Molecular cloning of the 5-HT $\mathrm{Hp}_{\mathrm{a} 1}$ receptor cDNA. The 5-HTap. $A$ fragment was PCR-amplified from DNA isolated from CNS and kidney cDNA libraries, using degenerate primers. The 5-HTap.B and 5-HTap.C cDNAs were isolated from a kidney cDNA library using a PCR-screening strategy (Israel, 1993). The 5-HTap.D was PCR-amplified from DNA isolated from the kidney cDNA library using nested antisense $5-\mathrm{HT}_{\mathrm{ap1}}$-specific primers and a sense (GT10-specific) primer. The reconstituted full-length cDNA is schematized at the bottom. The open reading frame is represented by boxes, and the putative transmembrane domains are indicated by the dark regions. The lines represent the $5^{\prime}$ and $3^{\prime}$ untranslated regions of the transcript.

thine (IBMX) were from Sigma-Aldrich (Oakville, Ontario, Canada). 5-Carboxamidotryptamine maleate (5-CT) and methiothepin mesylate were from Research Biochemicals (Natick, MA). Alprenolol hydrochloride, clozapine, dopamine hydrochloride, $( \pm)$-8-hydroxy-2-(di- $n$-propylamino) tetralin hydrobromide (8-OH-DPAT), ketanserin tartrate, mesulergine hydrochloride, metergoline, methysergide maleate, NAN-190 hydrobromide, $p$-aminophenethyl- $m$-trifluoromethylphenyl piperazine, $R-(+)-\mathrm{SCH}-23390$ hydrochloride, spiperone hydrochloride, and yohimbine hydrochloride were generous gifts from BioSignal Inc. (Montréal, Québec, Canada).

PCR amplification and screening of cDNA libraries. Phage DNAs (100 $\mathrm{ng}$ ) isolated from Aplysia kidney and CNS cDNA libraries constructed in the $\lambda \mathrm{GT} 10$ vector were PCR-amplified for 40 cycles $\left(94^{\circ} \mathrm{C}\right.$ for $1.5 \mathrm{~min}$, $40^{\circ} \mathrm{C}$ for $2 \mathrm{~min}$, and $72^{\circ} \mathrm{C}$ for $1 \mathrm{~min}$ ) in the presence of two primers corresponding to highly conserved 5-HT receptor sequences located in transmembrane domains 6 and 7: 5'-(G,C)IGCITT(T,C)ITIITITG(C,T) TGG(C,T)TGG(C,T)TICCITT(C,T)TT-3' and '5'-TCIGGII(A,T) (G,A)AAIATIG(T,C)(G,A)TA(G,A)ATIA(T,C)IGG(A,C)TT-3'. The PCR products were fractionated on a $4 \%$ agarose gel, and the $163 \mathrm{bp}$ fragment (5-HTap.A), present in both the CNS and kidney samples, was subcloned and sequenced (Fig. 1).

To clone the full-length cDNA, we used the PCR screening method previously described by Israel (1993). Briefly, an overnight culture of Escherichia coli strain LE392 was infected with $4 \times 10^{6}$ phages from an Aplysia kidney cDNA library. After an incubation at $37^{\circ} \mathrm{C}$ for $20 \mathrm{~min}$, the culture was diluted to $20 \mathrm{ml}$ and used to fill a 64-well plate with 20,000 phage per well. The plate was incubated at $37^{\circ} \mathrm{C}$ until the phage titer reached $\sim 1 \times 10^{9} \mathrm{pfu} / \mathrm{ml}$. Phage from eight wells across a row or eight wells down a column were pooled $(25 \mu \mathrm{l} /$ well $)$ and diluted 1:1 with distilled water. The matrix of 64 wells was therefore reduced to 16 pools, which were used as templates for PCR analysis. PCR reactions were performed in a final volume of $25 \mu \mathrm{l}$ using $0.5 \mu \mathrm{l}$ of pooled phage culture as template and $200 \mathrm{ng}$ of the degenerate primers described above. The reaction was held $10 \mathrm{~min}$ at $94^{\circ} \mathrm{C}$ to help phage denaturation before PCR amplification. PCR reaction products were electrophoresed through a 3\% agarose gel, transferred to a Hybond $\mathrm{N}+$ membrane (Amersham, Oakville, Ontario, Canada), and hybridized with the 5-HTap.A fragment at high stringency. Phage DNAs in wells located at the junction of positive rows and columns were individually PCR-amplified under the same conditions. Phages in single positive wells were plated and two clones, 5-HTap.B and 5-HTap.C (Fig. 1), were isolated using the plaquelifting method (Sambrook et al., 1989). Their inserts were subcloned and sequenced. To clone the missing $5^{\prime}$ end of the transcript, we PCR-amplified the isolated phage DNA from the kidney cDNA library, using a $\lambda$ GT10specific primer, 5'-AGCAAGTTCAGCCTGGTTAGTC-3', and two nested 5-HT ap1 $^{-}$-specific primers, 5'-GATGAGACTCAGAGGATGAC-3' and 5'-ATACAGCAACAGTTCAGG-3'. The product of the second PCR amplification (5-HTap.D) was subcloned in pCR 2.1 (Invitrogen, San Diego, CA) and sequenced (Fig. 1).
Cell lines. The coding region of 5-HT $\mathrm{H}_{\mathrm{ap} 1}$ was PCR-amplified with the primer pairs 5'-CAGCGAATTCCAGAGGATGGGAAGAAACG-3' and 5'-CCGCGAATTCTCACTACGTAATTCGGTTCAC-3' [nucleotides (nt) 320-1777], digested with Eco RI, and subcloned into the pBactmyc vector (Cravchik and Matus, 1993), in frame with the c-myc epitope EQKLISEEDLN (Degols et al., 1991). The pBact-myc/5-HT $\mathrm{Hp}_{1}$ construct was then partially digested with HindIII to remove the full-length c-myc/5-HT $\mathrm{H}_{\text {ap } 1}$ fragment, and the resulting fragment was subcloned in pCDNA3/RSV (Jockers et al., 1996). The recombinant plasmid was introduced into HEK 293 cells by calcium phosphate-mediated transfection, and the transfected cells were selected in Geneticin (Life Technologies, Burlington, Ontario, Canada), to establish permanent cell lines. Isolated foci were amplified, and expression of the receptor gene was confirmed by indirect surface immunofluorescence using a monoclonal c-myc-specific antibody (a kind gift of M. Bouvier, Université de Montréal, Montréal, Québec, Canada) and fluorescein-conjugated rabbit anti-mouse Igs (Dako, Mississauga, Ontario, Canada) as the secondary antibody. Cell lines expressing the highest levels of the receptor protein at the cell surface were used in the functional assays.

Ligand binding analysis. HEK cells expressing $5-\mathrm{HT}_{\mathrm{ap} 1}$ were grown to 90-100\% confluence, and membranes were prepared as described by Kohen et al. (1996). Membrane pellets were resuspended in (in mM): 75 Tris, $\mathrm{pH} 7.4,5 \mathrm{MgCl}_{2}$, and 2 EDTA buffer at a concentration of $\sim 250 \mu \mathrm{g}$ protein $/ \mathrm{ml}$. For saturation experiments, $10 \mu \mathrm{g}$ of membrane proteins were incubated in duplicate with increasing concentrations of tritiated lysergic acid diethylamide $\left(\left[{ }^{3} \mathrm{H}\right] \mathrm{LSD}, 71.5 \mathrm{Ci} / \mathrm{mmol} ; 1 \mathrm{Ci}=37 \mathrm{GBq}\right)$ for $60 \mathrm{~min}$ at room temperature in a total volume of $200 \mu \mathrm{l}$. Competition binding assays were done in duplicate with $10 \mu \mathrm{g}$ membrane proteins, in the presence of increasing concentrations of the competing agent $\left(10^{-12}-10^{-4} \mathrm{M}\right)$ and $1.5 \mathrm{nM}\left[{ }^{3} \mathrm{H}\right] \mathrm{LSD}$ for $60 \mathrm{~min}$ at room temperature. Preliminary assays had shown that saturation was reached within $30 \mathrm{~min}$ and remained stable for at least $2 \mathrm{hr}$ at room temperature (data not shown). All assays were terminated by rapid filtration over Whatman GF/C glass fiber filters (Xymotech Biosystems, Mt. Royal, Québec, Canada) and rinsed three times with $50 \mathrm{~mm}$ Tris, $\mathrm{pH}$ 7.4. Nonspecific binding was defined with $10 \mu \mathrm{M}$ methiothepin. The amount of bound $\left[{ }^{3} \mathrm{H}\right] \mathrm{LSD}$ was determined by scintillation spectrophotometry (Wallac 1409 liquid scintillation counter).

Adenylate cyclase activity. The cAMP content of cells stably expressing $5-\mathrm{HT}_{\mathrm{ap} 1}$ was measured by the prelabeling technique as described by Ansanay et al. (1992). Cells were cultured in 12-well plates. When apparent confluence was reached, cells were incubated with $2 \mu \mathrm{Ci} / \mathrm{ml}$ $\left[{ }^{3} \mathrm{H}\right]$ adenine. After $2-3 \mathrm{hr}$, the cultures were washed and incubated with $2.5 \mathrm{~mm}$ IBMX, $2.5 \mu \mathrm{M}$ forskolin, and the indicated drugs in a final volume of $1 \mathrm{ml}$ PBS for $20 \mathrm{~min}$ at $37^{\circ} \mathrm{C}$. The reaction was stopped by aspiration of the medium and addition of $1 \mathrm{ml}$ of ice-cold 5\% trichloroacetic acid. Cells were scraped with a rubber policeman, and $100 \mu$ l of a solution of $5 \mathrm{~mm}$ ATP and $5 \mathrm{mM}$ cAMP were added to the mixture. Cellular proteins were centrifuged at $5000 \times g$. $\left[{ }^{3} \mathrm{H}\right] \mathrm{ATP}$ and $\left[{ }^{3} \mathrm{H}\right] \mathrm{cAMP}$ were separated by sequential chromatography on Dowex and alumina columns (Bio-Rad, Mississauga, Ontario, Canada) (Salomon et al., 1974). cAMP formation corresponded to the conversion: $\left[{ }^{3} \mathrm{H}\right] \mathrm{cAMP} /\left(\left[{ }^{3} \mathrm{H}\right] \mathrm{ATP}+\left[{ }^{3} \mathrm{H}\right] \mathrm{cAMP}\right) \times$ 1000. Results are expressed as a percentage of the maximal cAMP accumulation.

Antibody production and immunoblotting. The $5-\mathrm{HT}_{\mathrm{ap} 1}$ sequence corresponding to the third cytoplasmic loop was PCR-amplified with the primer pair 5'-ATCAGAGCTCAGATATATCGCGCACGTCGG-3' and 5'-AACAAAGCTTGCCAGACTTTCCTTTCTCGC-3' (nt 10681523), digested with $S a c I$ and HindIII, and subcloned into the pQE30 prokaryote expression vector (Qiagen, Mississauga, Ontario, Canada), thus fusing a $6 \mathrm{XHis}$ tag to its N-terminal extremity. This domain of the protein was chosen because of the very low conservation of the primary structure of this region among different G-protein-coupled receptors. The fusion protein was purified on a nickel-nitrilo-tri-acetic acid resin column and used to inoculate rabbits for antibody production as described previously (Aloyz and DesGroseillers, 1995). For Western blotting, plasma membranes from freshly dissected tissues were prepared on a sucrose cushion as described in Bawab et al. (1992), electrophoresed on a $10 \%$ SDS polyacrylamide gel, and electroblotted onto nitrocellulose membranes. The nitrocellulose membranes were blocked with 5\% nonfat dry milk for $1 \mathrm{hr}$ at room temperature and then incubated with the primary antibody for $1 \mathrm{hr}$. After washing, the membrane was incubated with a horseradish peroxidase-conjugated secondary antibody (Dako) and immunoreactive bands were detected by a chemiluminescent substrate reaction (Pierce, Rockford, IL). 
$R T-P C R$. Reverse transcription experiments were performed on total RNA extracted from the desheathed ganglia of the nervous system and from the sheath itself. RNA was purified using Trizol reagent (Life Technologies) according to the manufacturer's instructions. RNA was reverse transcribed using an oligo- $\mathrm{dT}_{16}$ primer and Moloney murine leukemia virus reverse transcriptase (Perkin-Elmer, Foster City, CA) as described previously (Angers and DesGroseillers, 1998). A DNA fragment encompassing nt 1068-1523 was amplified using the same primers and conditions as described above. The presence of contaminating genomic DNA was monitored by amplification of the same samples without reverse transcription. The PCR products were fractionated on a $2 \%$ agarose gel and transferred to a Hybond $\mathrm{N}+$ membrane (Amersham) for hybridization with a specific oligonucleotide probe. As a positive control, we used actin primers as described by DesGroseillers et al. (1994).

\section{RESULTS}

\section{Isolation and structure of the gene encoding $5-\mathrm{HT}_{\mathrm{ap} 1}$}

The striking sequence conservation of transmembrane domains six and seven of G-protein-coupled receptors was used in a PCR approach to isolate a DNA fragment encoding the corresponding region of a putative 5-HT receptor in Aplysia. Using degenerate oligonucleotide primers, we amplified a $163 \mathrm{bp}$ fragment that shared $56 \%$ amino acid sequence identity with mammalian $5-\mathrm{HT}_{1 \mathrm{D}}$ receptors. These primers and the PCR-amplified fragment were then used to isolate two clones from a kidney cDNA library, using a PCR-based screening strategy (Fig. 1). The missing 5' end of the transcript was PCR-amplified with DNA isolated from the cDNA library, using nested oligonucleotides derived from the cDNA and a paired primer derived from the $\lambda \mathrm{GT} 10$ vector sequence.

The reconstituted cDNA is $1927 \mathrm{nt}$ long. Its longest open reading frame of $1476 \mathrm{nt}$ codes for a putative protein of 492 amino acids (Fig. 2). Hydrophobicity analysis of the deduced amino acid sequence revealed the presence of seven stretches of hydrophobic residues that represent the seven transmembrane domains characteristic to all G-protein-coupled receptors (data not shown). Amino acid sequence identity between $5-\mathrm{HT}_{\mathrm{ap} 1}$ and other 5-HT receptors within the transmembrane domains and adjacent regions is $62.4 \%$ to Lymnaea $5-\mathrm{HT}_{1 \mathrm{ym} 1} ; 54.7 \%$ to Drosophila $5-\mathrm{HT}_{\mathrm{dro2A}-\mathrm{B}} ; 51.8 \%$ to human $5-\mathrm{HT}_{1 \mathrm{~A}} ; 49.6 \%$ to human $5-\mathrm{HT}_{1 \mathrm{D}} ; 49.3 \%$ to human $5-\mathrm{HT}_{1 \mathrm{~F}} ; 47.8 \%$ to human $5-\mathrm{HT}_{1 \mathrm{E}}$; $47.1 \%$ to mouse $5-\mathrm{HT}_{1 \mathrm{~B}} ; 42.7 \%$ to mouse $5-\mathrm{HT}_{5 \mathrm{~A}-\mathrm{B}} ; 41.7 \%$ to mouse $5-\mathrm{HT}_{7} ; 41.2 \%$ to $5-\mathrm{HT}_{\mathrm{dro} 1} ; 35.6 \%$ to rat $5-\mathrm{HT}_{2 \mathrm{C}} ; 35.5 \%$ to Lymnaea $5-\mathrm{HT}_{1 \mathrm{ym} 2} ; 35.2 \%$ to rat $5-\mathrm{HT}_{4} ; 30.6 \%$ to Aplysia $5-\mathrm{HT}_{\text {apB1-2}}$; and $29.6 \%$ to rat $5-\mathrm{HT}_{6}$. A dendrogram analysis of amino acid sequence comparisons within the transmembrane domains indicates that $5-\mathrm{HT}_{\mathrm{ap} 1}$, along with other invertebrate 5-HT receptors, is associated with the mammalian $5-\mathrm{HT}_{1}$ receptor family (Fig. 3).

Six consensus sites for $\mathrm{N}$-linked glycosylation are present in the extracellular $\mathrm{N}$ terminus of $5-\mathrm{HT}_{\mathrm{ap} 1}$ (Fig. 2). Within the third cytoplasmic loop, seven serine or threonine residues may be used as a substrate for phosphorylation by protein kinase C. Another potential phosphorylation site for protein kinase $\mathrm{C}$ is found within the $\mathrm{C}$-terminal intracellular domain. A cysteine residue is also found in this domain, suggesting that the receptor may be palmitoylated. The structure of the receptor, with its large third cytoplasmic loop and its short C-terminal tail, is similar to that of the vertebrate $5-\mathrm{HT}_{1}$ receptor family, which groups receptors coupled to $G_{i}$ (Boess and Martin, 1994).

A Southern blot analysis of genomic DNA (Fig. 4) reveals the presence of a single band when the restriction enzyme used to digest the DNA has no restriction site in the region covered by the

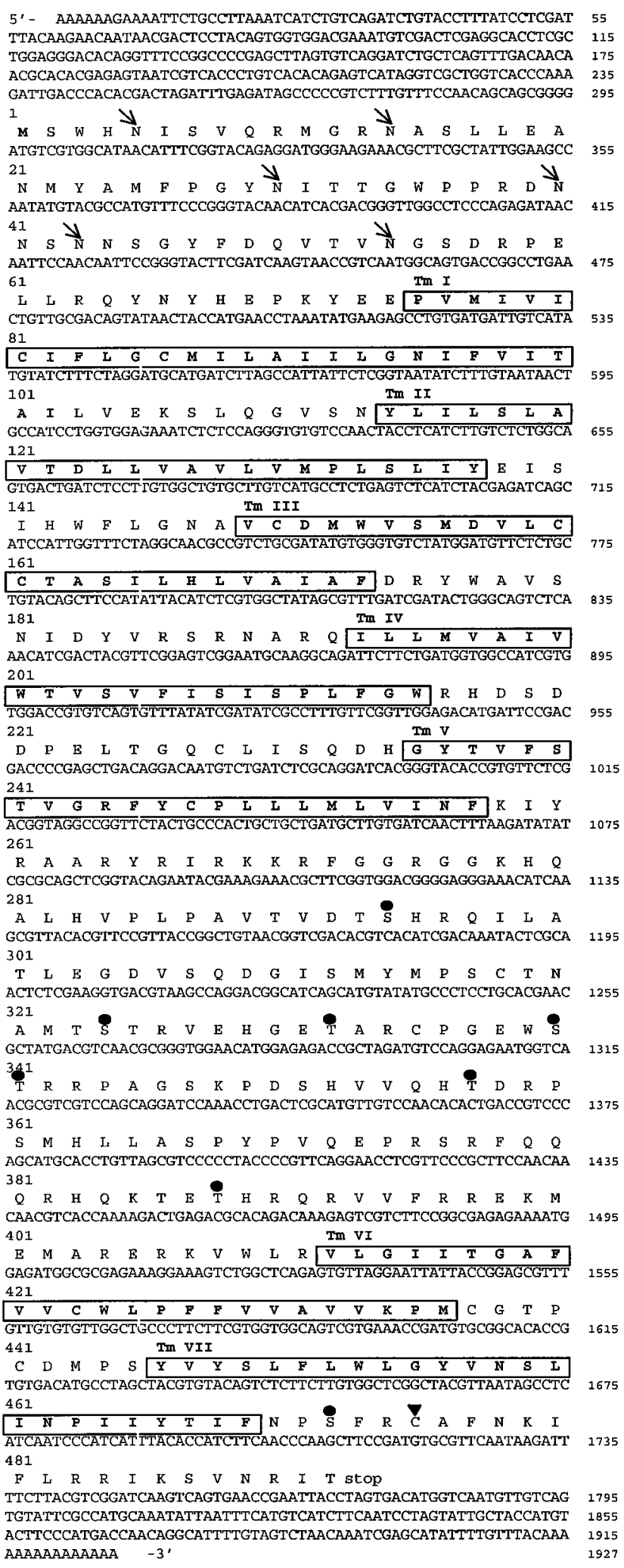

Figure 2. Nucleotide and deduced amino acid sequence of the 5-HT cDNA. Putative transmembrane regions are boxed and numbered TMIVII. Arrows indicate the position of consensus sites for N-linked glycosylation. Serines and threonines that are within a consensus sequence for phosphorylation by protein kinase $\mathrm{C}$ are indicated by circles $(\mathbf{\bullet})$. A potential palmitoylation site is indicated by a triangle $(\boldsymbol{\Delta})$. The nucleotide sequence is available in the GenBank database under accession number AF041039. 


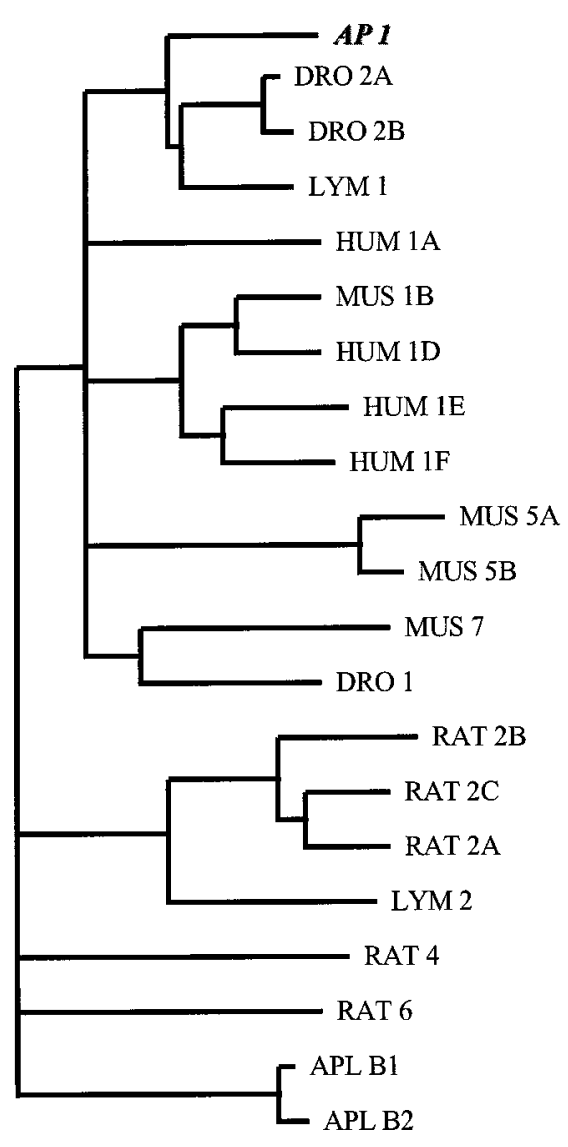

Figure 3. Phylogenetic analysis of 5-HT receptors. Amino acid sequences of 5-HT receptors were retrieved from the GenBank database. Their amino acid sequence, excluding their $\mathrm{N}$ termini and their third cytoplasmic loops, were aligned with the corresponding amino acid sequence of 5-HT $\mathrm{ap}_{1}$, using the ClustalW package (Thompson et al., 1994). The alignment was then used for phylogenetic comparisons using the PHYLIP package (J. Felsenstein, 1993, PHYLIP 3.5.1c; University of Washington, Seattle, WA). Analysis was performed with a bootstrap procedure that computes the probability of occurrence of the branches for 100 possible trees. Branching order was determined using the FitchMargoliash algorithm included in the PHYLIP package. Only branches occurring in $>80$ trees are represented. HUM, human; MUS, mouse; $R A T$, rat.

probe and two bands when the restriction site is present in the cDNA probe sequence. This indicates that the gene is probably intronless. This conclusion was confirmed by partial sequencing of a genomic clone and PCR amplification of genomic DNA (data not shown). The Southern blot analysis also indicates that $5-\mathrm{HT}_{\mathrm{ap} 1}$ is unique in the genome and does not have a close homolog. This is in contrast to the Aplysia 5-HT $\mathrm{Hp}_{\text {ap1 }}$ and $5-\mathrm{HT}_{\mathrm{apB} 2}$ receptors, which share $86 \%$ identity at the nucleotide level (Li et al., 1995).

\section{Pharmacology}

The coding region of $5-\mathrm{HT}_{\mathrm{ap} 1}$ was cloned in an expression vector in fusion with a c-myc epitope at its $\mathrm{N}$ terminus. The vector was transiently expressed in COS-7 and HEK 293 cells, and the expression of the receptor at the plasma membrane was monitored with the anti-myc antibodies (data not shown). The receptor with its myc tag was then used to transfect mammalian HEK 293 cells to establish permanent cell lines. Membranes isolated from one of these cell lines bound $\left[{ }^{3} \mathrm{H}\right] \mathrm{LSD}$ in a saturable and dose-dependent manner with an estimated $K_{\mathrm{d}}$ of $0.56(0.03 \mathrm{nM})$

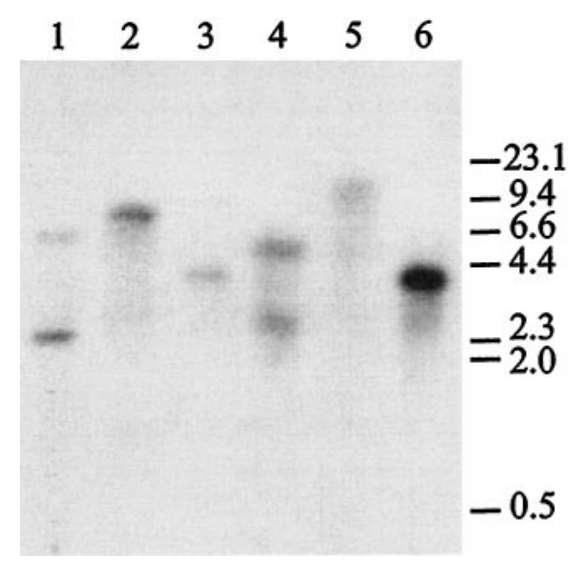

Figure 4. Southern blot analysis of the $5-\mathrm{HT}_{\mathrm{ap} 1}$ gene. Genomic DNA was isolated from ovotestis, purified, and digested with BamHI (lane 1), BglII (lane 2), Eco RI (lane 3), HindIII (lane 4), SacI (lane 5), or XbaI (lane 6), as described previously (Wickham and DesGroseillers, 1991). Digested DNA was run on a $1 \%$ agarose gel, transferred to a Hybond $\mathrm{N}+$ membrane, and hybridized with a ${ }^{32} \mathrm{P}$-labeled 5-HTap.B cDNA fragment (nt 457-1927). BglII, EcoRI, SacI, and XbaI sites are not present in the probe sequence, whereas BamHI and HindIII appear once. The molecular weight marker is $\lambda$ phage DNA digested with HindIII. The molecular weights are indicated in kilobase pairs.

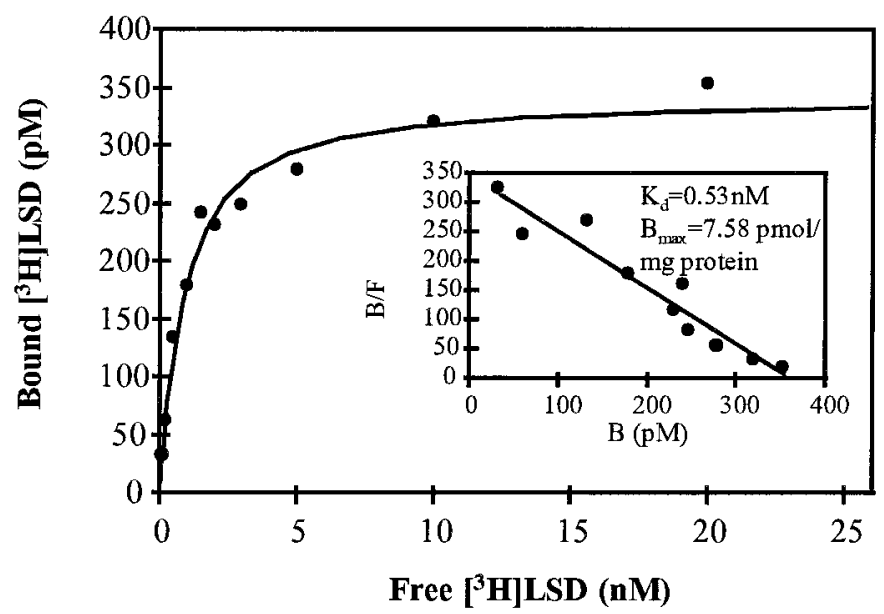

Figure 5. Saturation analysis of $\left[{ }^{3} \mathrm{H}\right] \mathrm{LSD}$ binding on the $5-\mathrm{HT}_{\mathrm{ap} 1}$ receptor. Membranes harvested from stable cell lines expressing $5-\mathrm{HT}_{\mathrm{ap} 1}$ were incubated with increasing concentrations of [ $\left.{ }^{3} \mathrm{H}\right] \mathrm{LSD}(0.1-20 \mathrm{nM})$ for $1 \mathrm{hr}$ at room temperature. Nonspecific binding was defined in the presence of $10 \mu \mathrm{M}$ unlabeled methiothepin. Results are those of a single experiment, but similar results were obtained in six different binding experiments. The $K_{\mathrm{d}}$ and $B_{\max }$ values were determined with the AllFit for Windows 2.1 computer program (C. De Léan and A. De Léan, 1993, Université de Montréal, Montréal, Québec, Canada). Inset, Scatchard plot of the same data.

and a receptor density of $6.89(0.61 \mathrm{pmol} / \mathrm{mg}$ of protein; $n=3)$ (Fig. 5). Similar results were obtained from two independent cell clones and from transiently transfected COS-7 cells, for a mean $K_{\mathrm{d}}$ of $0.51(0.13 \mathrm{~nm} ; n=6)$. Of course, receptor density varied in each transfection experiment and in each clone tested.

The rank order of potency of various serotonergic agonists and antagonists for the inhibition of $\left[{ }^{3} \mathrm{H}\right] \mathrm{LSD}$ binding to HEK membranes is listed in (Table 1) and illustrated in Figure 6. Briefly, $5-\mathrm{HT}_{\text {ap1 }}$ showed high-affinity binding to 5-HT, which is comparable to the affinity of 5-HT for the mammalian 5-HT $1 \mathrm{~A}, \mathrm{~B}, \mathrm{D}-\mathrm{F}$, and 5- $\mathrm{HT}_{7}$ receptors (Hoyer et al., 1994). Compounds that show high 


\begin{tabular}{lc}
\hline $\begin{array}{l}\text { Table 1. Affinities of various compounds that compete with the binding } \\
\text { of } 1.5 \text { nM }\left[^{\mathbf{3}} \mathbf{H}\right] \mathbf{L S D} \text { to the membranes of HEK } 293 \\
\text { cells stably } \\
\text { transfected with the 5-HT }{ }_{\text {ap1 }} \text { gene }\end{array}$ \\
Drug & $K_{\mathrm{i}}(\mathrm{nM})$ \\
\hline 5-CT & 1,04 \\
Methiothepin & 2,62 \\
PAPP & 9.50 \\
5-HT & 13.23 \\
Methysergide & 15.01 \\
Clozapine & 56.63 \\
8-OH-DPAT & 73.96 \\
Metergoline & 90.66 \\
Yohimbine & 222.37 \\
Mesulergine & 245.52 \\
Ketanserin & 288.18 \\
SCH 23390 & 616.14 \\
NAN 190 & $>1000$ \\
Dopamine & $>1000$ \\
Spiperone & $>1000$ \\
Alprenolol & $>1000$
\end{tabular}

$\overline{\text { Affinity estimates are given as } K_{\mathrm{i}} \text { values in nanomolar concentrations and were }}$ determined by a computer-assisted nonlinear curve analysis (De Léan and De Léan, $1993) . K_{\mathrm{i}}$ values are expressed as the mean of at least three different determinations.

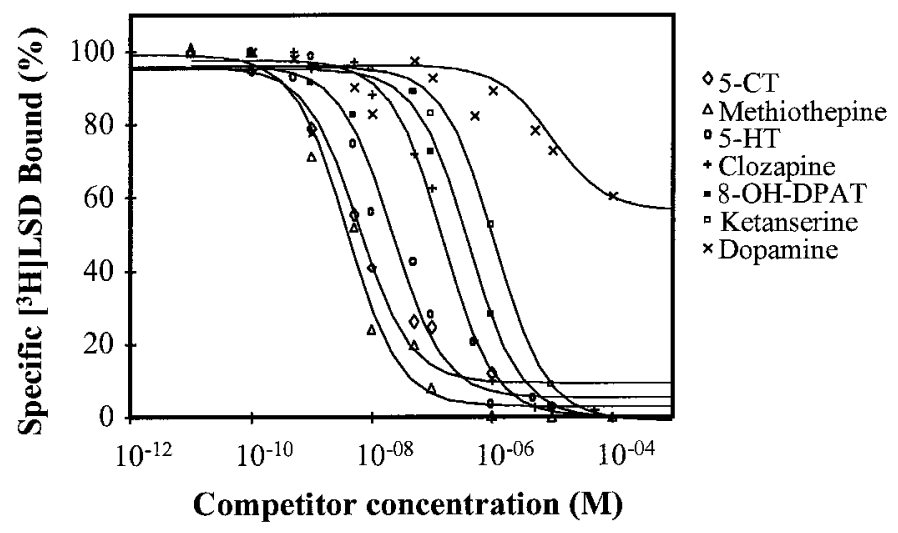

Figure 6. Inhibition of specific [ $\left.{ }^{3} \mathrm{H}\right] \mathrm{LSD}$ binding to the Aplysia $5-\mathrm{HT}_{\mathrm{ap} 1}$ receptor. Membranes from stable cell lines expressing $5-\mathrm{HT}_{\mathrm{ap} 1}$ were incubated with $1.5 \mathrm{nM}\left[{ }^{3} \mathrm{H}\right] \mathrm{LSD}$ in the presence or absence of increasing concentrations of unlabeled competitors. Nonspecific binding was defined in the presence of $10 \mu \mathrm{M}$ unlabeled methiothepin. Results at each concentration are presented as a percentage of the specific binding in the absence of the competitor. Results are from a single experiment but are representative of three such experiments. Data were analyzed by a computer-assisted nonlinear analysis (C. De Léan and A. De Léan, 1993, AllFit for Windows 2.1; Université de Montréal).

binding affinity to the mammalian $5-\mathrm{HT}_{1}$ receptors, such as $5-\mathrm{CT}$, methiothepin, PAPP, and methysergide, also bound $5-\mathrm{HT}_{\mathrm{ap} 1}$ in the nanomolar range. By contrast, metergoline, clozapine, mesulergine, and ketanserin, compounds that bind to $5-\mathrm{HT}_{2}$ receptors

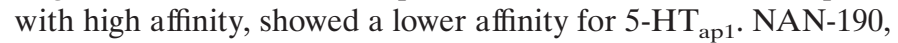
a very specific $5-\mathrm{HT}_{1 \mathrm{~A}}$ antagonist, showed very poor affinity for

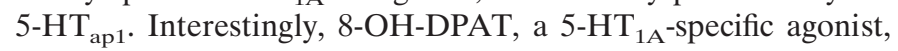
bound $5-\mathrm{HT}_{\mathrm{ap} 1}$ with a better affinity than most other 5-HT receptors, except for 5-HT $\mathrm{HT}_{1 \mathrm{~A}}$ itself. Very high concentrations of dopamine, spiperone, or alprenolol were necessary to displace $\left[{ }^{3} \mathrm{H}\right] \mathrm{LSD}$ binding, confirming the serotonergic nature of 5-HT $\mathrm{Hp}_{\mathrm{a} 1}$. Overall, the pharmacological profile of $5-\mathrm{HT}_{\mathrm{ap} 1}$ seems related to

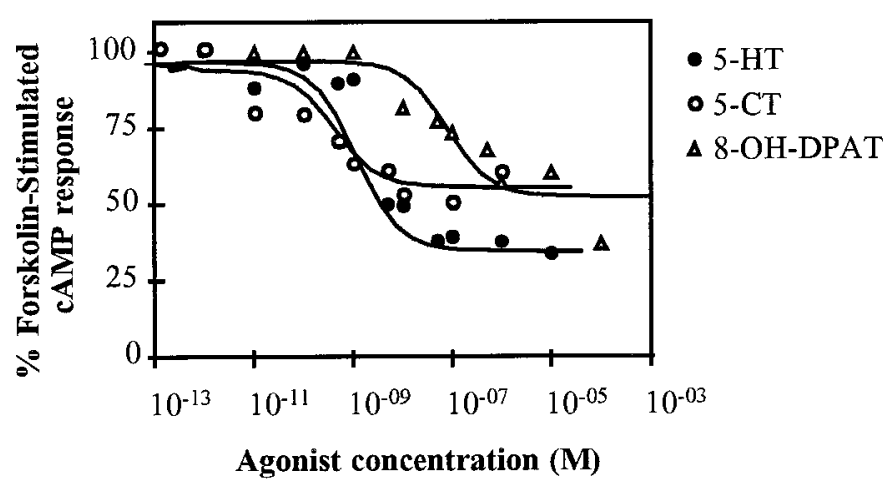

Figure 7. 5-HT- and agonist-induced decrease in cAMP levels in cell lines expressing the 5- $\mathrm{HT}_{\mathrm{ap} 1}$ receptor. cAMP levels are expressed as a percentage of the value obtained with $2.5 \mu \mathrm{M}$ forskolin $(100 \%)$ in the absence of 5-HT or agonists. The values are the mean of an experiment done in triplicate and are representative of three such experiments. Data were analyzed by a computer-assisted nonlinear analysis (C. De Léan and A. De Léan, 1993, AllFit for Windows 2.1; Université de Montréal).

the $5-\mathrm{HT}_{1}$ and $5-\mathrm{HT}_{7}$ receptor profiles, although not clearly associated with either one.

\section{Functional coupling}

The molecular structure and pharmacological profile of 5-HTap1 suggested that this receptor is coupled to $G_{i}$ and therefore could inhibit adenylate cyclase. To verify this hypothesis, we measured the accumulation of $\left[{ }^{3} \mathrm{H}\right] \mathrm{cAMP}$ in the $5-\mathrm{HT}_{\mathrm{ap} 1}$-expressing $\mathrm{HEK}$ cells after application of 5-HT or agonists. As expected, forskolin-induced cAMP accumulation was efficiently inhibited by $5-\mathrm{HT}$ and the other serotonergic agonists, 5-CT and $8-\mathrm{OH}-$ DPAT, in a dose-dependent manner (Fig. 7). The concentrations of agonists at which inhibition of adenylate cyclase was effective corresponded to those that were shown to be necessary for competing $\left[{ }^{3} \mathrm{H}\right] \mathrm{LSD}$ binding. 5-HT produced no inhibition of cAMP accumulation in the presence of $100 \mathrm{nM}$ methiothepin. 5-HT concentrations ranging from $10 \mathrm{nM}$ to $10 \mu \mathrm{M}$ had no effect on cAMP levels in untransfected HEK cells treated with forskolin (data not shown). Altogether, these experiments demonstrate that $5-\mathrm{HT}_{\mathrm{ap} 1}$ is functionally coupled to the mammalian $\mathrm{G}_{\mathrm{i}}$ subunit, and that it inhibits adenylate cyclase and cAMP accumulation in the heterologous expression system.

\section{5-HT ${ }_{\text {ap1 }}$ protein distribution}

Plasma membrane extracts from various Aplysia tissues were prepared and used in an immunoblot analysis to detect the presence of the receptor. Different bands ranging in size from 45 to $71 \mathrm{kDa}$ were detected in the gill, heart, hermaphroditic duct, kidney, and ovotestis extracts (Fig. $8 A$ ). To determine whether the differences in the size of the receptor can be explained by different patterns of glycosylation, kidney membrane extracts were treated with deglycosidase F (New England Biolabs, Mississauga, Ontario, Canada) and separated by SDS-PAGE. After treatment, the observed molecular weight of the receptor is decreased to $45 \mathrm{kDa}$, which is the size expected from the cDNA sequence (Fig. $8 B$ ). In the CNS, the protein is detected in all ganglia, as well as in the sheath, with the strongest signal observed in the abdominal and pedal ganglia (Fig. 9A). These results were confirmed by RT-PCR experiments. The mRNA could be amplified from all desheathed ganglia but not from the sheath itself (Fig. 9B). There is a poor correlation between the mRNA and 
$\mathbf{A}$

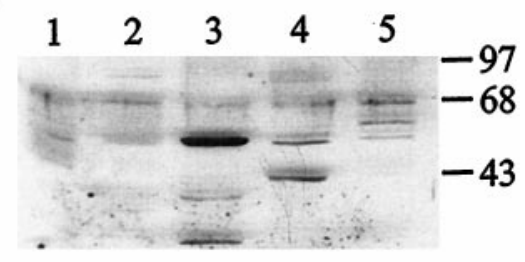

B

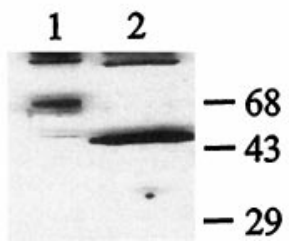

Figure 8. Western blot analysis of the expression of the 5-HT $\mathrm{H}_{\mathrm{ap} 1}$ receptor in different Aplysia tissues. Proteins were resolved by SDS-PAGE and analyzed by immunoblotting with antiserum raised against the third cytoplasmic loop of the $5-\mathrm{HT}_{\mathrm{ap} 1}$ receptor. $A$, Thirty micrograms of cytoplasmic membrane protein extracts prepared from gill (lane 1), heart (lane 2), hermaphroditic duct (lane 3), kidney (lane 4), and ovotestis (lane 5 ). $B$, Fifty micrograms of kidney plasma membrane proteins before (lane 1) or after (lane 2) treatment with deglycosidase $\mathrm{F}$ to remove $\mathrm{N}$-linked sugars. Molecular weight marker positions are indicated in kilodaltons.

protein levels, suggesting that the protein is expressed at the level of the nerve terminals.

\section{DISCUSSION}

We have isolated and characterized an Aplysia 5-HT receptor that belongs to the G-protein-coupled receptor family. Its structure and biochemical properties are closely related to those of the invertebrate $5-\mathrm{HT}_{1 \mathrm{ym} 1}$ and $5-\mathrm{HT}_{\mathrm{dro} 2 \mathrm{~A}-2 \mathrm{~B}}$ and to those of the vertebrate $5-\mathrm{HT}_{1}$ receptor subtypes. The absence of introns in the gene, the presence of a large third cytoplasmic loop and a short $\mathrm{C}$-terminal domain in the protein, and a functional coupling to the inhibition of adenylate cyclase in stably transfected cells are all features of the $5-\mathrm{HT}_{1}$ receptor subfamily. $5-\mathrm{HT}_{\mathrm{ap} 1}$ is therefore clearly associated with this vertebrate receptor subfamily. Two other 5-HT receptors have recently been cloned in Aplysia (Li et al., 1995). These receptors are closely related to each other and are linked to the phospholipase $\mathrm{C}$ pathway. They show very little sequence identity with $5-\mathrm{HT}_{\mathrm{ap} 1}$ and therefore are clearly members of another subfamily of 5-HT receptors. In Lymnaea, a 5-HT receptor with some similarities to vertebrate $5-\mathrm{HT}_{1}$ receptors has been cloned (Sugamori et al., 1993). However, its functional coupling to a second messenger system has not been determined, and its pharmacological profile is different from that of $5-\mathrm{HT}_{\mathrm{ap} 1}$, suggesting that they may not be homologous.

Like other invertebrate G-protein-coupled receptors (Saudou et al., 1992; Li et al., 1995; Gerhardt et al., 1997), 5-HT $\mathrm{H}_{\text {ap } 1}$ is efficiently coupled to mammalian G-proteins when expressed in mammalian cells. This underlines the high conservation among species of members of the G-protein-coupled receptor subfamily and the functional conservation of mechanisms that link these receptors to G-proteins. In this respect, it is not surprising to observe that the biochemical characterization of $\mathrm{G}_{\mathrm{s} \alpha}, \mathrm{G}_{\mathrm{o} \alpha}$, and $\mathrm{G}_{\mathrm{i} \alpha}$, as well as $\mathrm{G}_{\beta}$, in the Aplysia nervous system has demon-
$\mathbf{A}$
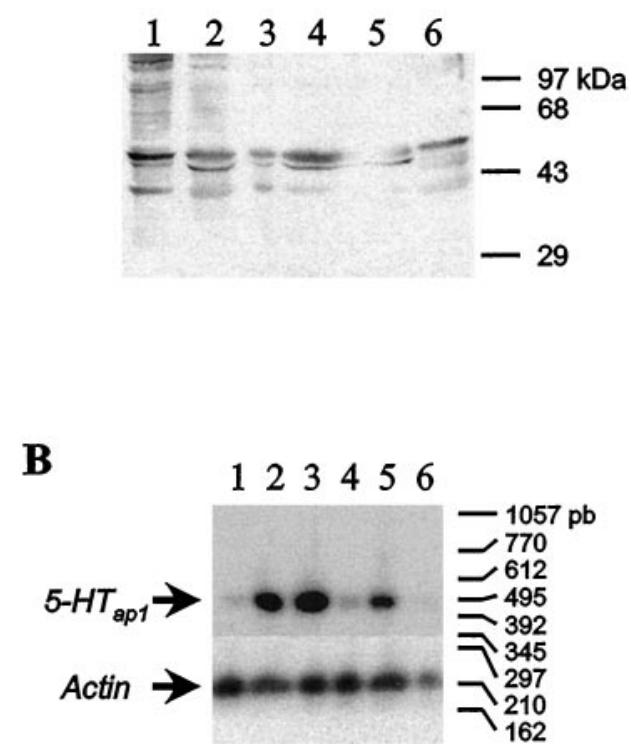

Figure 9. Western blot and RT-PCR analysis of the expression of the $5-\mathrm{HT}_{\mathrm{ap} 1}$ receptor in the CNS. $A$, Fifty micrograms of total protein extracted from desheathed ganglia and sheath alone were resolved by SDS-PAGE and analyzed by immunoblotting with antiserum raised against the third cytoplasmic loop of the $5-\mathrm{HT}_{\mathrm{ap} 1}$ receptor. Abdominal (lane 1), buccal (lane 2), cerebral (lane 3), pedal (lane 4), and pleural (lane 5 ) ganglia from five animals were pooled. The sheath extract (lane 6 ) was prepared from a single animal. $B$, RT-PCR analysis was conducted on total RNA isolated from the same samples as in $A$. The PCR products were analyzed by Southern blotting probed with a $5-\mathrm{HT}_{\mathrm{ap} 1}$-specific oligonucleotide. The same procedure was followed for amplification of the control (actin). The sizes of the bands were estimated by comparison with the DNA size markers on the original ethidium bromide-stained gel.

strated that these proteins are very similar to their mammalian counterparts (Critz et al., 1986; Vogel et al., 1989).

The pharmacological profile of 5- $\mathrm{HT}_{\mathrm{ap} 1}$ is also reminiscent of

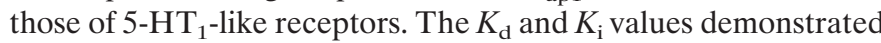
the high affinity of the 5- $\mathrm{HT}_{\mathrm{ap} 1}$ receptor for LSD, 5-CT, methiothepin, and 5-HT and are comparable to the values obtained with vertebrate 5-HT $\mathrm{HT}_{1}$ receptors (Boess and Martin, 1994). Interestingly, these ligands bind to all vertebrate $5-\mathrm{HT}_{1}$ receptor subtypes with high affinity. By contrast, ligands that show a high specificity to the $5-\mathrm{HT}_{1 \mathrm{~A}}$ receptors, such as $8-\mathrm{OH}-\mathrm{DPAT}$ and NAN-190, do not bind $5-\mathrm{HT}_{\mathrm{ap} 1}$ efficiently. Their binding efficiency is more closely related to that of the $5-\mathrm{HT}_{7}$ receptor than to those of other vertebrate $5-\mathrm{HT}_{1}$ receptors (Ruat et al., 1993). These results suggest that the structure and function of the $5-\mathrm{HT}_{\mathrm{ap} 1}$ receptor are probably closely related to those of an ancestor gene, which existed before the divergence of the 5-HT receptor subtypes in vertebrates, and that it kept characteristics of more than one receptor subtype. Therefore, $5-\mathrm{HT}_{\mathrm{ap} 1}$ may be closer to the prototype of the early $5-\mathrm{HT}_{1,7}$ receptors.

This view is in agreement with previous phylogenetic studies that suggested that the major subfamilies of 5-HT receptors diverged early in evolution to form three major subclasses: the 5- $\mathrm{HT}_{1}$ (which includes 5- $\mathrm{HT}_{5}$ and 5- $\mathrm{HT}_{7}$ ), 5- $\mathrm{HT}_{2}$, and 5- $\mathrm{HT}_{6}$ receptor subclasses (Peroutka and Howell, 1994; also see Fig. 3). This divergence occurred before the evolution of vertebrates from invertebrates, and one can expect to find members of these major subclasses in invertebrate species (Peroutka, 1994). Further division within the $5-\mathrm{HT}_{1}$ and $5-\mathrm{HT}_{2}$ subfamilies seems to have 
occurred after the separation of vertebrates and invertebrates, and homologs of these subtypes may not be found in mollusks. More than one $5-\mathrm{HT}_{1}$ receptor may nevertheless be found in Aplysia and in other invertebrates, but they will have emerged independently from vertebrate receptors.

The pharmacological profile of a receptor depends on the conservation of amino acids in and around the binding site of the receptor (Hibert et al., 1991; Ho et al., 1992; Chanda et al., 1993; van Rhee and Jacobson, 1996). Therefore, it is not surprising to find that the pharmacological profiles of mollusks and mammals are difficult to compare, considering the large phylogenetic distances. Nevertheless, whatever its pharmacological profile, the characterization of the second messenger pathway with which the receptor is linked clearly associates $5-\mathrm{HT}_{\mathrm{ap} 1}$ to the $5-\mathrm{HT}_{1}$ subfamily and not to $5-\mathrm{HT}_{7}$.

Very few 5-HT-dependent pathways have been characterized on a pharmacological basis in Aplysia. None of these generated a $5-\mathrm{HT}_{\mathrm{ap} 1}$-like pharmacological profile. In earlier works, binding experiments using crude membrane preparations of different tissues revealed a $\left[{ }^{3} \mathrm{H}\right] \mathrm{LSD}$ binding site with a dissociation constant of $0.63 \mathrm{~nm}$ (Drummond et al., 1980). Similar results were obtained on tissue sections using $\left[{ }^{125} \mathrm{I}\right] \mathrm{LSD}$ (Kadan and Hartig, 1988). Although this value is consistent with our data on the $5-\mathrm{HT}_{\mathrm{ap} 1}$ receptor expressed in mammalian cells, competition of the LSD binding sites in the crude tissue membranes with 5-HT gave $K_{\mathrm{i}}$ values at least two orders of magnitude higher than the one observed for 5-HT ${ }_{\text {ap1 }}$ (Drummond et al., 1980; Kadan and Hartig, 1988). In addition, Drummond et al. (1980) demonstrated that there was a good correlation between the amount of $\left[{ }^{3} \mathrm{H}\right] \mathrm{LSD}$ binding sites and the amount of 5-HT-induced adenylate cyclase activity in most tissues. Altogether, these results suggest that although $5-\mathrm{HT}_{\mathrm{ap} 1}$ is expressed in all these tissues, it was not recognized in these binding assays. It also suggests that more than one 5-HT receptor is present in most Aplysia tissues, and therefore, the binding assay with Aplysia tissue membranes probably recognized a heterogeneous population of receptors, with similar affinities for LSD.

More recently, Ram et al. (1994) reported the existence of an Aplysia $5-\mathrm{HT}_{1 \mathrm{~A}}$-like receptor in the Aplysia buccal muscle. In this system, 5-HT is known to potentiate the acetylcholine-elicited contractions. This effect was shown to be efficiently competed by NAN-190 in the nanomolar range and mimicked by 8-OH-DPAT in the micromolar range, thus defining a $5-\mathrm{HT}_{1 \mathrm{~A}}$-like site. However, this receptor is likely to be different from $5-\mathrm{HT}_{\mathrm{ap} 1}$, because we showed that 5-HT ${ }_{\text {ap } 1}$ does not bind NAN-190 at these concentrations. These last observations strongly suggest that at least

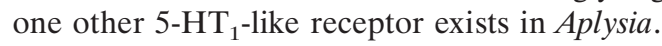

The application of 5-HT has generally been associated with an increase in cAMP levels in Aplysia. Nevertheless, application of 5-HT often triggers inhibitory responses, although the downstream pathway is not yet determined (Jennings et al., 1981; Xu et al., 1995). In addition, functional coupling of a receptor may vary in different cell types, and stimulation of a single receptor subtype may mediate different responses under different physiological conditions. For example, the mammalian $5-\mathrm{HT}_{1 \mathrm{~A}}$ receptor has been shown to inhibit adenylate cyclase via its interaction to $G_{i}$ protein and also to nonenzymatically mediate the opening of $\mathrm{K}^{+}$ channels via an interaction with a different, unidentified G-protein subunit (Andrade et al., 1986). Moreover, it is known that the stimulation of different $\mathrm{G}_{\mathrm{i}}$-coupled receptors in different cell types leads to the activation of MAP kinase through the $\mathrm{G}_{\beta \gamma}$ subunits (Koch et al., 1994). The presence of 5-HT ap1 $_{1}$ in many
Aplysia tissues suggests that it may play a variety of roles linked to the inhibition of adenylate cyclase, activation of MAP kinase, and/or modulation of other pathways. It will be particularly interesting to determine whether $5-\mathrm{HT}_{\mathrm{ap} 1}$ is expressed in some sensory neuron clusters of the CNS (Storozhuk et al., 1998) and whether it is involved in the 5-HT-induced activation of MAP kinase in these cells. This activation is implicated in the establishment of long-term facilitation in cultured neurons (Martin et al., 1997). Further investigation of the roles of the 5-HT $\mathrm{Ap}_{\mathrm{a}}$ receptor in this animal is susceptible to give interesting new data on this aspect of cell signaling.

\section{REFERENCES}

Aloyz RS, DesGroseillers L (1995) Processing of the L5-67 precursor peptide and characterization of LUQIN in the LUQ neurons of Aplysia californica. Peptides 16:331-338.

Andrade R, Malenka RC, Nicall RA (1986) A G-protein couples serotonin and $\mathrm{GABA}_{\mathrm{B}}$ receptors to the same channels in hippocampus. Science 234:1261-1265.

Angers A, DesGroseillers L (1998) Alternative splicing and genomic organization of the L567 gene of Aplysia californica. Gene 208:271-277.

Ansanay H, Sebben M, Bockaert J, Dumuis A (1992) Characterization of homologous 5-hydroxytryptamine ${ }_{4}$ receptor desensitization in colliculi neurons. Mol Pharmacol 42:808-816.

Bacskai BJ, Hochner B, Mahaut-Smith M, Adams SR, Kaang BK, Kandel ER, Tsien RY (1993) Spatially resolved dynamics of cAMP and protein kinase A subunits in Aplysia sensory neurons. Science 260:222-226.

Bawab W, Querido E, Crine P, DesGroseillers L (1992) Identification and characterization of aminopeptidases from Aplysia californica. Biochem J 286:967-975.

Boess FG, Martin IL (1994) Molecular biology of 5-HT receptors. Neuropharmacology 33:275-317.

Braha O, Dale N, Hochner B, Klein M, Abrams TW, Kandel ER (1990) Second messengers involved in the two processes of presynaptic facilitation that contribute to sensitization and dishabituation in Aplysia sensory neurons. Proc Natl Acad Sci USA 87:2040-2044.

Byrne JH, Kandel ER (1996) Presynaptic facilitation revisited: state and time dependence. J Neurosci 15:425-435.

Chanda PK, Minchin MCW, Davis AR, Greenberg L, Reilly Y, McGregor WH, Bhat R, Lubeck MD, Mizutani S, Hung PP (1993) Identification of residues important for ligand binding to the human 5-hydroxytryptamine ${ }_{1 \mathrm{~A}}$ serotonin receptor. Mol Pharmacol 43: 516-520.

Cravchik A, Matus A (1993) A novel strategy for the immunological tagging of cDNA constructs. Gene 137:139-143.

Critz SD, Harper JF, Byrne JH (1986) Evidence for the inhibitory subunit of adenylate cyclase $\left(\mathrm{N}_{\mathrm{i}}\right)$ in nervous tissue of Aplysia. Neurosci Lett 64:145-150.

Degols G, Leonetti JP, Mechti N, Lebleu B (1991) Antiproliferative effects of antisense oligonucleotides directed to the RNA of c-myc oncogene. Nucleic Acids Res 19:935-938.

DesGroseillers L, Auclair D, Wickham L, Maalouf M (1994) A novel actin cDNA is expressed in the neurons of Aplysia californica. Biochim Biophys Acta 1217:322-324.

Drummond AH, Bucher F, Levitan IB (1980) Distribution of serotonin and dopamine receptors in Aplysia tissues: analysis by $\left[{ }^{3} \mathrm{H}\right] \mathrm{LSD}$ binding and adenylate cyclase stimulation. Brain Res 184:163-177.

Emptage NJ, Carew TJ (1993) Long-term synaptic facilitation in the absence of short-term facilitation in Aplysia neurons. Science 262:253-256.

Gerhardt CC, Leysen JE, Planta RJ, Vreugdenhil E, Van Heerikhuizen H (1997) Functional characterization of a 5- $\mathrm{HT}_{2}$ receptor cDNA cloned from Lymnaea stagnalis. Eur J Pharmacol 311:249-258.

Gerschenfeld HM, Paupardin-Tritsch D (1974) On the transmitter function of 5-hydroxytryptamine at excitatory and inhibitory monosynaptic junctions. J Physiol (Lond) 243:457-481.

Ghirardi M, Braha O, Hochner B, Montarlo PG, Kandel ER (1992) Roles of PKA and PKC in facilitation of evoked and spontaneous transmitter release at depressed and nondepressed synapses in Aplysia sensory neurons. Neuron 9:479-489.

Hen R (1993) Structural and functional conservation of serotonin receptors throughout evolution. In: Comparative molecular neurobiology (Pichon Y, ed), pp 266-278. Basel: Birkhäuser. 
Hibert MF, Trumpp-Kallmeyer S, Bruinvels A, Hoflack J (1991) Threedimensional models of neurotransmitter G-binding protein-coupled receptors. Mol Pharmacol 40:8-15.

Ho BY, Karschin A, Branchek T, Davidson N, Lester HA (1992) The role of conserved aspartate and serine residues in ligand binding and in function of the 5-HT $1 \mathrm{~A}$ receptor: a site-directed mutation study. FEBS Lett 312:259-262.

Hoyer D, Clarke DE, Fozard JR, Hartig PR, Martin GR, Mylecharane EJ, Saxena PR, Humphrey PPA (1994) VII. International union of pharmacology classification of receptors for 5-hydroxytryptamine (serotonin). Pharmacol Rev 46:157-203.

Israel DI (1993) A PCR-based method for high stringency screening of DNA libraries. Nucleic Acids Res 21:2627-2631.

Jennings KR, Host JJ, Kaczmarek LK, Strumwasser F (1981) Serotonergic inhibition of afterdischarge in peptidergic bag cells. J Neurobiol 12:579-590.

Jockers R, Da Silva A, Strosberg AD, Bouvier M, Marullo S (1996) New molecular and structural determinants involved in $\left({ }_{2}\right.$-adrenergic receptor desensitization and sequestration. J Biol Chem 271:9355-9362.

Kadan MJ, Hartig PR (1988) Autoradiographic localization and characterization of $\left[{ }^{125} \mathrm{I}\right]$ lysergic acid diethylamide binding to serotonin receptors in Aplysia. Neuroscience 24:1089-1102.

Koch WJ, Hawes BE, Allen LF, Lefkowitz RJ (1994) Direct evidence that $\mathrm{G}_{\mathrm{i}}$-coupled receptor stimulation of mitogen-activated protein kinase is mediated by $\mathrm{G}_{\beta \gamma}$ activation of $\mathrm{p} 21^{\text {ras. }}$. Proc Natl Acad Sci USA 91:12709-12710.

Kohen R, Metcalf MA, Khan N, Druck T, Huebner K, Lachowicz JE, Meltzer HY, Sibley DR, Roth BL, Hamblin MW (1996) Cloning, characterization, and chromosomal localization of a human $5-\mathrm{HT}_{6}$ serotonin receptor. J Neurochem 66:47-56.

Li X-C, Giot J-F, Kuhl D, Hen R, Kandel ER (1995) Cloning and characterization of two related serotonergic receptors from the brain and the reproductive system of Aplysia that activate phospholipase C. J Neurosci 15:7585-7591.

Martin KC, Michael D, Rose JC, Barad M, Casadio A, Zhu H, Kandel ER (1997) MAP kinase translocates into the nucleus of the presynaptic cell and is required for long-term facilitation in Aplysia. Neuron 18:899-912.

Mercer AR, Emptage NJ, Carew TJ (1991) Pharmacological dissociation of modulatory effects of serotonin in Aplysia sensory neurons. Science 254:1811-1813.

Peroutka SJ (1994) 5-Hydroxytryptamine receptors in vertebrates and invertebrates: why is there so many? Neurochem Int 25:533-536.

Peroutka SJ (1995) 5-HT receptors: past, present, and future. Trends Neurosci 18:68-69.

Peroutka SJ, Howell TA (1994) The molecular evolution of G-protein- coupled receptors: focus on 5-hydroxytryptamine receptors. Neuropharmacology 33:319-324.

Ram JL, Judge K, Jednak MA (1994) Antagonists of cholinergic and serotonergic responses of Aplysia buccal muscle. Comp Biochem Physiol [C] 107:235-242.

Ruat M, Traiffort E, Leurs R, Tardivel-Lacombe J, Diaz J, Arrang JM, Schwartz JC (1993) Molecular cloning, characterization, and localization of a high-affinity serotonin receptor $\left(5-\mathrm{HT}_{7}\right)$ activating cAMP formation. Proc Natl Acad Sci USA 90:8547-8551.

Sambrook J, Fritsch EF, Maniatis T (1989) Molecular cloning, a laboratory manual, Ed 2. Cold Spring Harbor, NY: Cold Spring Harbor Laboratory.

Salomon Y, Londos C, Rodbell M (1974) A highly sensitive adenylate cyclase assay. Anal Biochem 58:541-548.

Saudou F, Boschert U, Amlaiky N, Plassat JL, Hen R (1992) A family of Drosophila serotonin receptors with distinct intracellular signalling properties and expression patterns. EMBO J 11:7-17.

Storozhuk MV, Castellucci VF, DesGroseillers L (1998) Differential effect of 5-HT on synaptic connections of the RF sensory neurons in the abdominal ganglion of Aplysia. Soc Neurosci Abstr, in press.

Sugamori KS, Sunahara RK, Guan H-C, Bulloch AGM, Tensen CP, Seeman P, Niznik HB, Van Tol HHM (1993) Serotonin receptor cDNA from Lymnaea stagnalis. Proc Natl Acad Sci USA 90: $11-15$.

Sugita S, Goldsmith JR, Baxter DA, Byrne JH (1992) Involvement of protein kinase $\mathrm{C}$ in serotonin-induced spike broadening and synaptic facilitation in sensorimotor connections of Aplysia. J Neurophysiol 68:643-651.

Thompson JD, Higgins DG, Gibson TJ (1994) CLUSTAL W: improving the sensitivity of progressive multiple sequence alignment through sequence weighting, position-specific gap penalties and weight matrix choice. Nucleic Acids Res 22:4673-4680.

van Rhee AM, Jacobson KA (1996) Molecular architecture of G-protein-coupled receptors. Drug Dev Res 37:1-38.

Vogel SS, Chin GJ, Mumby SM, Schonberg M, Schwartz JH (1989) G-proteins in Aplysia: biochemical characterization and regional and subcellular distribution. Brain Res 478:281-292.

Weiger WA (1997) Serotoninergic modulation of behavior: a phylogenetic overview. Biol Rev Camb Philos Soc 72:61-95.

Wickham L, DesGroseillers L (1991) A bradykinin-like neuropepide precursor gene is expressed in neuron L5 of Aplysia californica. DNA Cell Biol 10:249-258.

Xu Y, Pieroni JP, Cleary LJ, Byrne JH (1995) Modulation of an inhibitory interneuron in the neural circuitry for the tail withdrawal reflex of Aplysia. J Neurophysiol 73:1313-1318. 